\title{
Decline of European Corn Borer as a Pest of Potatoes
}

Thomas P. Kuhar, Department of Entomology, Eastern Shore AREC, Virginia Tech, Painter, VA 23420; Gerald Ghidiu, Rutgers

Agricultural Research and Extension Center, Bridgeton, NJ 08302;

and Hélène B. Doughty, Department of Entomology, Eastern Shore AREC, Virginia Tech, Painter, VA 23420

Corresponding author: Thomas P. Kuhar. tkuhar@vt.edu

Kuhar, T. P., Ghidiu, G., and Doughty, H. B. 2010. Decline of European corn borer as a pest of potatoes. Online. Plant Health Progress doi: 10.1094/PHP-2010-0129-01-PS.

European corn borer (ECB), Ostrinia nubilalis (Hübner), is regarded as a significant pest in North America. Larvae bore into stems, stalks, or the fruit of a wide range of agricultural crops. In the Mid-Atlantic United States, potatoes are an attractive early-season crop for the first generation of ECB moths, which deposit egg masses from mid to late May $(3,5)$. Neonates feed on leaves for a few days before tunneling into stems typically in the leaf axil at the node (Fig. 1). Most larval tunneling occurs in the lower third of main stems, and a single larva can make multiple tunnels in a single plant (5). Tunneling near the base of stems causes breakage and lodging as well as entry points for stem rot pathogens such as Erwinia carotova (3). For these reasons, Mid-Atlantic potato growers have traditionally sprayed insecticides for ECB each season. Because sampling for this pest is difficult, most growers typically spray preventatively. Some commonly-used insecticides for ECB control have included carbofuran (Furadan), methyl parathion (Penncap-M), cyfluthrin (Baythroid), permethrin (Pounce), and lambda-cyhalothrin (Warrior).

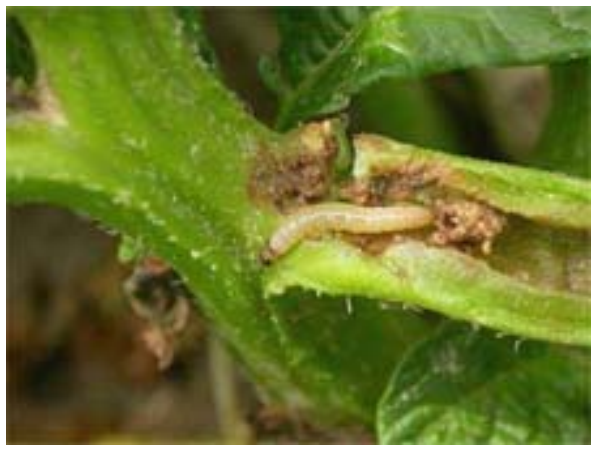

Fig. 1. European corn borer larva in potato stem.

We believe that these foliar insecticide applications for ECB are generally not needed on potatoes today in the Mid-Atlantic. We present the following reasons to support our claim:

1. In general, ECB does not cause economic damage to potatoes. Extensive research in North Carolina showed that over $50 \%$ of potato stems may be tunneled by ECB without significant loss of tuber yield $(5,6,7)$. Further, depending on timing of infestation and variety, nearly $100 \%$ of stems can be infested without economic yield loss, particularly in the absence of disease pathogens. Similar results were found in NewJ ersey using plants artificially infested with ECB egg masses (1). Additional unpublished research from Michigan, Maine, Maryland, and Virginia also found it difficult to detect any yield loss in potatoes from ECB tunneling. Thus, it is probably safe to state that natural ECB infestations rarely cause economic damage to potatoes, particularly in the absence of disease pathogens. 
2. Population levels of ECB appear to have declined in recent years in many regions along the eastern and central United States. The reason for this apparent decline is not definitively known, but most likely involves the increased use of transgenic Bt corn, which provides virtually $100 \%$ control of ECB. Since ECB utilizes corn as its major host plant for food and reproduction (4), ECB population dynamics will undoubtedly be negatively impacted in areas where Bt corn dominates the agricultural landscape. This phenomenon can be demonstrated in Painter, VA, where ECB pest management research has been conducted for several decades, and where Bt corn use on the surrounding farmland of the Delmarva Peninsula has increased steadily over the last 10 years. Historical counts of ECB moths caught in a black light trap located in Painter have shown a distinct drop over the past decade (Fig. 2). Similarly, there has been a decline in ECB damage in the untreated control plots from potato and bell pepper insecticide experiments over that same time period (Fig. 3). Evidence of ECB decline has been reported in the Midwestern United States as well (8). Annual fall surveys of overwintering ECB larvae have shown evidence of landscape-scale suppression by Bt corn (2). 


\section{Peak weekly catch of moths Painter, VA}

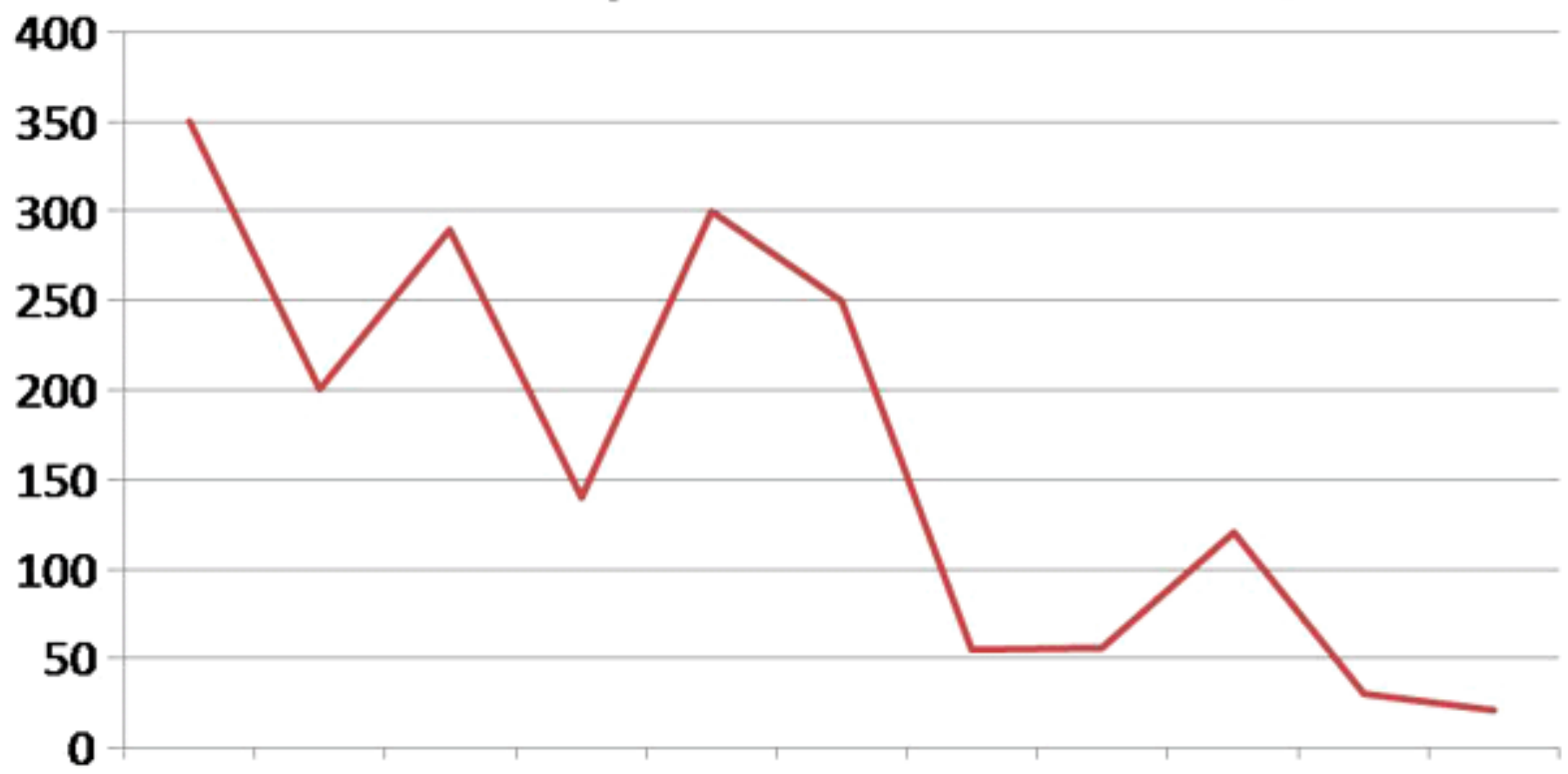

Fig. 2. European corn borer peak moth catch from 1998 to 2008 in a blacklight trap located in Painter, VA.

\section{\% ECB damage to potatoes and bell peppers}

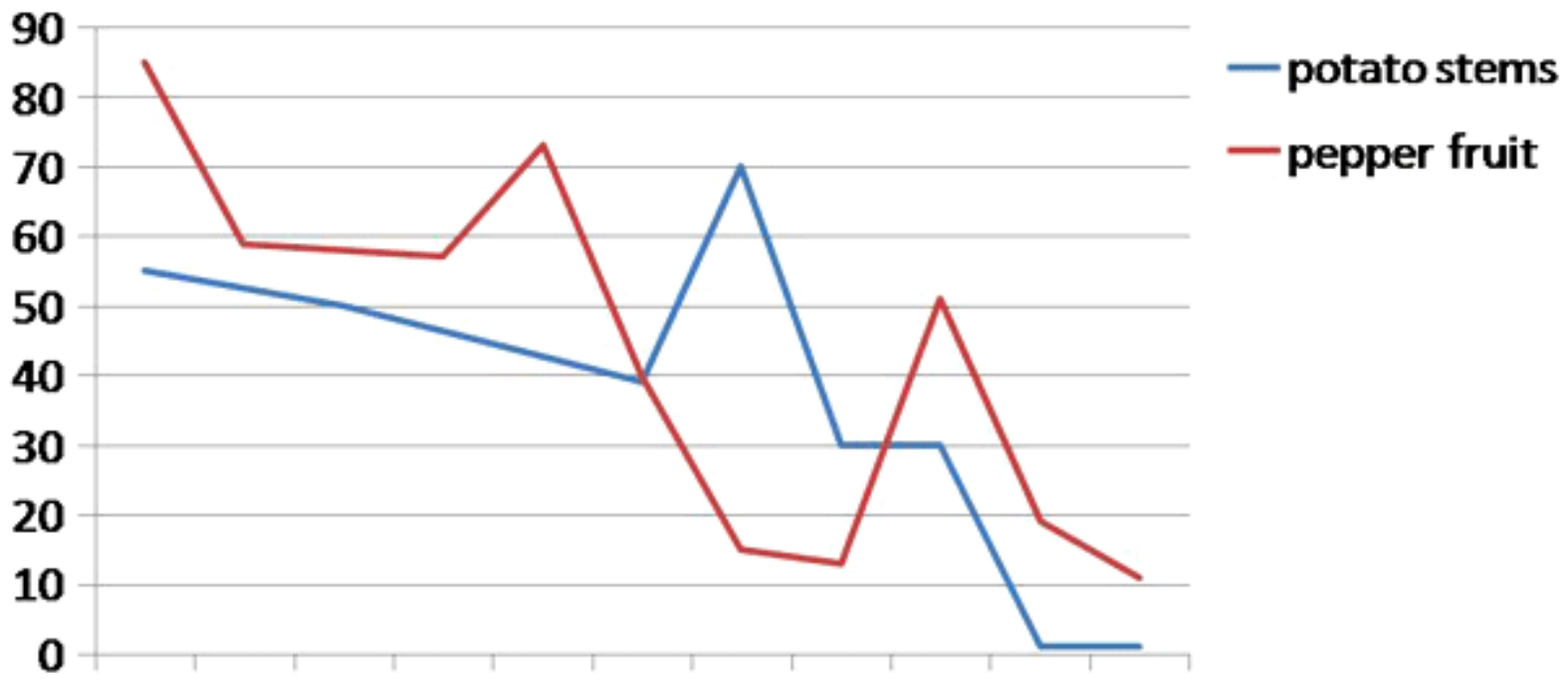

Fig. 3. European corn borer damage to potato stems or bell pepper fruit from untreated control plots in insecticide efficacy experiments conducted in Painter, VA.

3. Many non-target insecticide applications will control ECB. According to a recent survey in Virginia, many potato growers have begun applying the insecticide fipronil (Regent) at-planting for control of wireworms in the soil. Though applied in-furrow, fipronil moves systemically in the potato plant and is quite efficacious against ECB larvae. Insecticide trials conducted over the past decade in Painter, VA, have shown very few, if any, ECB tunnels in potatoes that were treated at-planting with fipronil (Fig. 4). In addition, several other foliar insecticides such as spinosad, spinetoram, novaluron, and chlorantraniliprole that primarily target Colorado potato beetle, Leptinotarsa decemlineata, are also efficacious against ECB. When potato growers rotate to these newer chemistries, particularly for insecticide resistance management of Colorado potato beetle, they will also likely provide control of ECB as the spray timings in May are similar for these pests. 


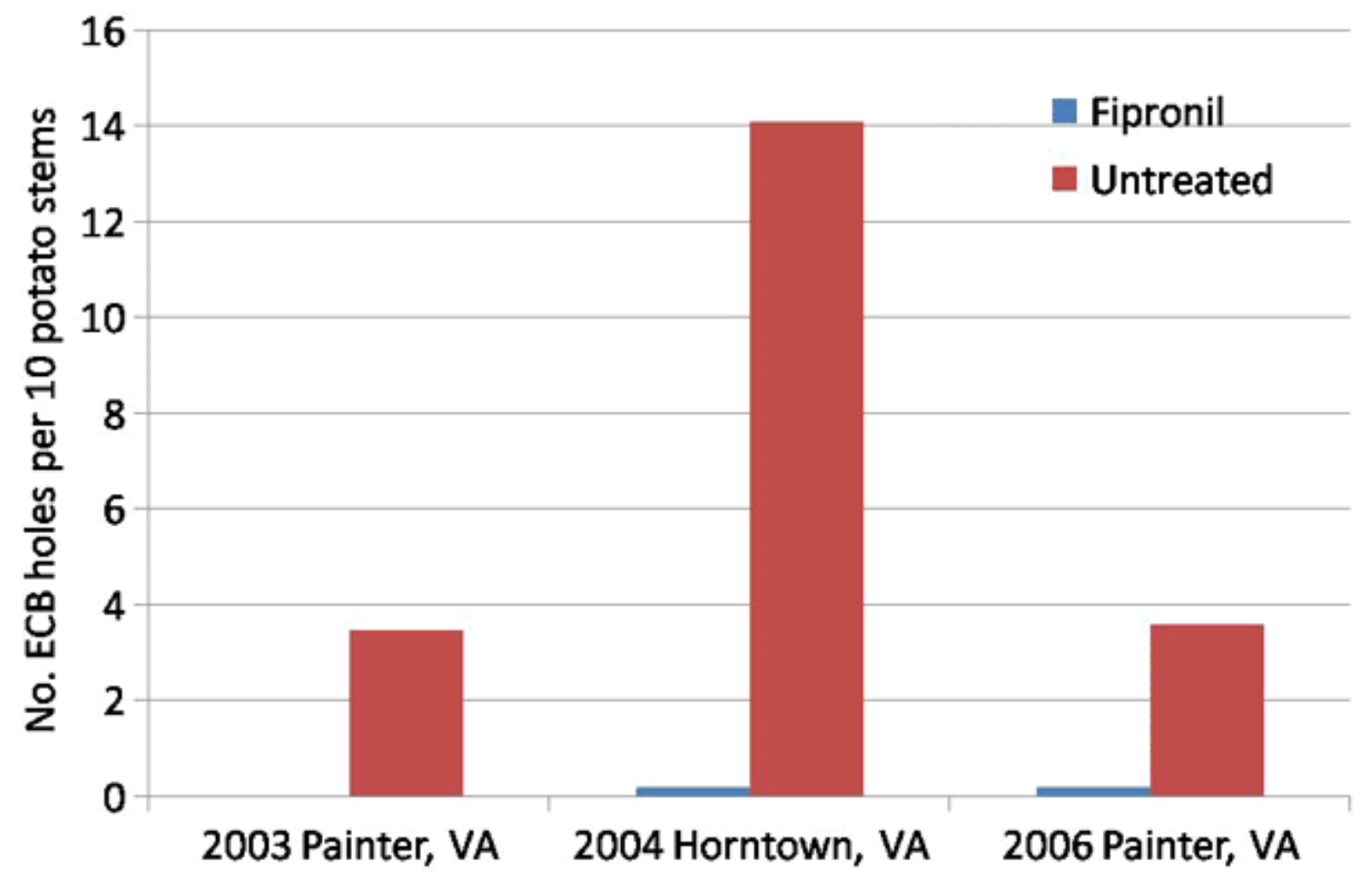

Fig. 4. European corn borer stem injury in potatoes treated at-planting with fipronil (Regent 4SC) at $0.1 \mathrm{lb}$ ai/acre or untreated from three insecticide efficacy experiments conducted on the Eastern Shore of Virginia.

In summary, although the European corn borer has been considered an important agricultural pest in the past, its rank as a primary foliar pest in potatoes has increasingly declined. Recent studies and observations have pointed to a sharp decline in population density, an overall high economic injury level for potatoes, and sufficient control from insecticides applied for other pests. The European corn borer's customary control in potatoes may therefore no longer be needed in the Mid-Atlantic United States, and perhaps other regions as well.

\section{Literature Cited}

1. Ghidiu, G. M. 1998. Effects of European corn borer egg mass levels on yields of white potatoes. Pages 19-20 in: Vegetable Entomology Research Results 1998. New J ersey Agric. Res. Bull. 104G. Rutgers Univ., New Brunswick, NJ .

2. Hutchison, W. D., Burkness, E. C., Moon, R., Leslie, T., Fleischer, S., and Abrahamson, M. 2007. Evidence for regional suppression of European corn borer populations in transgenic Bt maize in the Midwestern U.S.: analysis of long term time series data from three states. Pagers 512-513 in: Proc. XVI Intl. Plant Protection Congress 2007. Glasgow, Scotland.

3. Kennedy, G. G. 1983. Effects of European corn borer (Lepidoptera: Pyralidae) damage on yields of spring-grown potatoes. J. Econ. Entomol. 76:316-322.

4. Kennedy, G. G., and Storer, N. P. 2000. Life systems of polyphagous pests in temporally unstable cropping systems. Annu. Rev. Entomol. 45:467-493.

5. Nault, B. A., and Kennedy, G. G. 1996. Timing insecticide applications for managing European corn borer (Lepidoptera: Pyralidae) infestations in potato. Crop Prot. 15:465-471.

6. Nault, B. A., French N. M., II, and Kennedy, G. G. 1996. Influence of European corn borer (Lepidoptera: Pyralidae) damage to potato and foliage availability on overwinter survival of first generation Colorado potato beetle adults (Coleoptera: Chrysomelidae) in North Carolina. J. Econ. Entomol. 89:124-130. 
7. Nault, B. A., Speese J., III, Kennedy, G. G., Linduska, J ., and Dively, G. 2001. Response of potato tuber yield to stem injury by European corn borer (Lepidoptera: Crambidae) in the Mid-Atlantic United States. J . Econ. Entomol. 94:1162-1169.

8. Steffey, K., and Gray, M. 2007. Is the European corn borer an endangered species? Online. The Bulletin: Pest Management and Crop Development Information for Illinois, No. 24 (3), November. Univ. of Illinois, Urbana-Champaign, IL. 